\title{
THE EFFECT OF LECTORA INSPIRE-BASED INTERACTIVE LEARNING MEDIA IN VOCATIONAL HIGH SCHOOL
}

\author{
Nur Rahmi Akbarini \\ Master of Economic Education, Sebelas Maret University Surakarta \\ arinnur44@gmail.com \\ Wiedy Murtini \\ Master of Economic Education, Sebelas Maret University Surakarta \\ idik_53@yahoo.co.id \\ Andre N Rahmanto \\ Master of Economic Education, Sebelas Maret University Surakarta \\ andreyuda@yahoo.com
}

\begin{abstract}
The objective of research was to reveal: (1) the learning outcome of students in experiment class, (2) the learning outcome of students in control class, (3) the effect of lectora inspire-based interactive learning media on the learning outcome of students. This study was a quasi-experiment research with Pretest-Posttest Control Design with students of SMK Negeri 6 Surakarta being the subject of research. The instruments used in this research were questionnaire and test. The result of research showed that: (1) the learning outcome for experiment class indicated mean posttest value of 84.53, (2) the learning outcome for control class indicated mean posttest value of 71.73 , and (3) there was an effect of Lectora Inspire-based interactive learning media on the learning outcome of students, as can be seen from the result of $t$-test calculation with $t$ statistic $0,000<t$ table 0.05. The conclusion of research was that there was a difference of effect of lectora inspirebased interactive learning media application on the learning outcome of students between control and experiment classes.
\end{abstract}

Kata kunci: interactive learning media, public administration, learning outcome 


\section{INTRODUCTION}

Technology era developing today highly affects human life. The activity is formerly manual in nature now changes into the technology-based one. It is well-established if human resource should be able to follow the existing development to compete in global era. Education improvement is one of ways to produce human resource as expected. The government as the forefront guard of Indonesia country always attempts to improve human resource, one of which is the implementation of 2013 Curriculum.

Implementation of 2013 Curriculum inflict the pros and cons. However, the government gave the reason that curriculum changes were made because the previous curriculum was considered to be burdensome to students. Many lesson materials can be learned by the students, thus making it burdened. Implementation 2013 Curriculum is part of the continuing development of Competency Based Curriculum (Kurikulum Berbasis Kompetensi/KBK), which was initiated in 2004 by covering the competence of cognitive, affective, and psychmotor in an integrated manner.

The 2013 Curriculum is implemented from primary school to secondary school. The 2013 Curriculum emphasizes on learning process with scientific method in which the learning model used is supported by technology-based learning media. Ogott \& Odera's (2012, pp. 792-793) study found that more than $85 \%$ of teachers use neither media nor technology resource during the learning, while $80 \%$ of them say that integration of media and technology is very helpful in learning realization. Recalling the importance of it, teacher as facilitator in school should be able to apply technology-based learning media.

Formal schools developing within society are required to use the 2013 Curriculum, one of which is Vocational Middle School (Sekolah Menengah Kejuruan, thereafter called SMK). SMK is a formal education equivalent to Senior High School/Islamic Senior High School (SMA/MA), but its students are prepared to enter directly into job realm. In addition, Wibisono, Baedowi, \& Indrawati's (2017, p. 204) study stated that the competency of SMK students should be improved, recalling the high unemployment rate in SMK graduates. Central Statistic Bureau (BPS) mention Unemployment rate is dominated mostly by SMK graduates. On August 2017 the unemployment rate increases by 10 thousands people to 7.04 million people of total workforce. It is this that underlies the importance of learning media use in SMK. This is an attempt to improve process and learning outcomes.

Media is an important component in learning. Currently the government is concentrate on building infrastructure in order to support learning in the classroom . In-school programs have been carried out on an ongoing basis, these efforts need the support of teachers to implement the learning in school. The media expected is the one that can explain the abstract subject into the concrete one visualized into more meaningful and attractive images.

One subject in the 2013 Curriculum, particularly in office administration major of SMK, is public administration. Public Administration subject is important to conceive as it is the basic of other subjects to be taken in the 11 th grade. This subject is theoretical in nature and needs interactive media that can attract the students' attention. Public Administration learning occurs in two ways to enable the students participating actively in the learning because learning is not an end but it is a process toward achieving the objective (Hamalik, 2009, p. 29).

Administration is a function that plays an important role towards the achievement of smooth business activities, as well as activities undertaken by the organization. Administration activities can be regarded as the lifeblood of the organization. Proper understanding of the administration is indispensable for the provision of students in the face of future employment situation.

The result of field observation on SMK Negeri 6 Surakarta shows that public administration learning occurring is still conventional, students tend to be passive, and teachers utilize the existing infrastructure less optimally. Whereas the existing infrastructure at SMK Negeri 6 Surakarta, including complete and in good condition. Teachers must be able to take advantage of this by making innovative learning media.

Teachers only use traditional learning methods, namely by noting what is described. 
Teachers use a single source textbooks, and students do not have the book. Not many students who have the textbooks appropriate 2013 Curriculum. This should encourage teachers to seek more learning resources. Reciprocal relationships between teachers and students do not occur. Students receive input from the teacher without giving an opinion. Some students get bored and instead talk to their friends. If this happens on an ongoing basis, the effectiveness of the learning will not be realized.

It impacts on the learning outcome of students, as confirmed with the fact that $51.85 \%$ of students still have score below minimum learning passing. It indicates that more than a half of students have not absorbed yet the learning material. This condition is, of course, contrary to the expectation of 2013 Curriculum emphasizing on student centered.

Learning outcome is a form success of teachers in delivering the material to students. According to Rifa'i \& Anni (2011, p. 85) learning outcome is obtained students behavior changes after experiencing learning activities. Marks given to the learning outcomes in the form of numbers or letters. Learning outcomes affect the motivation and enthusiasm of students to learn more. After the learning, students were expected to undergo changes towards a more intellectual kind.

Basically, the learning success is not only based on the acquisition of cognitive abilities, but also based on affective and psychomotor ability. Cognitive ability related to the results in the form of knowledge, skills and intellectual skills. Affective ability related to feelings, attitudes, interests, and values. Psychomotor ability related to physical abilities such as motor skills and nerves, object manipulation, and nerve coordination. From this description is a learning process in the classroom is very important to note.

Learning media is a means of delivering learning material more straightly and attractively, thereby generating reciprocal relation between teacher and students. The use of learning media can improve the students' interest and willingness in a subject (Wirawan, Indrawati, \& Rahmanto, 2017, p. 79). Students' self-interest can stimulate curiosity, thereby improving learning activity. It is in line with Naz \& Akbar (2008, pp. 35-36) stating that learning media increases commu- nication process because students participate more actively. If learning media is designed correctly, learning media affects the learning significantly and positively.

The more rapidly development of technology has allowed media provides a constructivist learning environment in which students can solve problem by means of active participation in learning process. This kind of learning environment causes a person to have more knowledge and become more dynamic. Technology support aims to annihilate students' views reluctance about learning and can make learning more effective. This matter enables the teachers to make innovation in the learning media they use.

One of solutions to improving the learning outcome of public administration is to conduct learning using an interactive learning media. Interactive learning media means media that combines text, graphics, video, animation and sound, to deliver a message and information. Media such as that referred generally to stimulate students to think more deeply. Weigel (2009, pp. 13-15), in his study, revealed that interactive learning media is a factor affectingly strongly the implementation of learning wherever, whenever, and however the learning process runs.

Learning using interactive media offer many advantages both for students and for teachers. Interactive learning media is not difficult to manufacture. A lot of software that can be used, one of which Lectora Inspire. Lectora Inspire is software that has developed within society; this software provides an interactive learning media with understandable and developable feature to beginner users (Minkova, 2016; Çelik, 2012). Lectora Inspire produced and released in 1999 by trivantis corporation founded by Timothy D Loudermilk. In 2011, Lectora obtained 5 awards in innovative E-Learning products, Authoring Tool, best presentation tool, and best elearning technology (Mas'ud, 2013).

The facilitation presented by Lectora Inspire is a distinctive advantage. The advantages of lectora inspire according to Minkova (2016, p. 2587) was ability to create interactions by using drag and drop, multiple tools for interactions such as lists and dictionaries section, built in themes, recording screen simulation with the possibility of video recording and learning mode, improved sound 
editing functions, numerous advantaged features for additing script and variable, ability to direct student to specific learning units based on their assessment. It is in line with FuiLeow \& NeoTheng $(2014$, p. 101) stating that the media designed using lectora inspire will increase the students' learning motivation in learning process and the teachers' teaching creativity.

Lectora Inspire-based interactive learning media is expected to have a positive impact on learning. Therefore, a study should be conducted on the effect of Lectora Inspirebased interactive learning media to improve the learning outcome of students in SMK Negeri 6 Surakarta.

\section{METHOD}

This research was conducted using quasi-experiment method. Quasi experiment is the research comparing the effect of a treatment administration on an object (experiment) and seeing the achievement of learning outcome as the result of its treatment effect.

Population is a generalization region consisting of: objects / subjects that have a certain quantity and characteristics that can be determined by researchers to learn and then drawn conclusions (Sugiyono, 2016, p. 135). The population of research consisted of all students in Office Administration major of SMK Negeri 6 Surakarta, containing 108 students.

The sample is part of the characteristics possessed by the population. For various reasons (example because it is impossible, unnecessary, or unnecessary and impossible) not all things can be explained or need to be researched, so only the sample is checked (Budiyono 2003, p. 34). The sampling technique used was non-probability sampling with purposive sampling technique to select experiment and control classes out of the classes existing with certain criteria (Sugiyono, 2016, p. 68).

Purposive sampling technique was conducted because this technique took the sample with the following criterion: the class has mean score of 68 in previous basic competency. Meanwhile, the classes with similar mean score were the 10th Office Administration 1 and 2 grades, each of which consisted of 30 students.

\section{RESULT AND DISCUSSION}

The work procedure of collecting data was as follows: (1) library study involves: identifying standard competency and prior characteristic of students, determining basic competency, selecting material, determining learning model, developing media and organizing the learning process; (2) preparing syllabus and learning implementation plan (RPP); (3) developing an interactive media; (4) learning stage; and (5) evaluation and report writing stage.

Library study involves: identifying standard competency and prior characteristic of students, determining basic competency, selecting material, determining learning model, developing media and organizing the learning process.

Furthermore, a syllabus and learning implementation plan compiled with details as follows:

a. Competence based used is 3.2, 4.2 and 3.3, 4.3 with the material organization and personnel administration

b. Teachers use time is $2 \times 45$ minutes of each meeting, which consists of four sessions of three meetings to convey the material and one meeting to posttest

c. Learning model that is used not only lecture but with discussion and other learning model which will be delivered through interaktif learning media lectora inspire

Then, developing an interactive media using lectora-inspire software. Media is arranged coherently in accordance with the syllabus and learning implementation plan. Media has passed the test media expert, material expert, linguist, and Practitioners with very good criterion.

In the learning stage, the author conducted pretest in the beginning of meeting in both control and experiment class using the same question. Thereafter, students in experiment class were treated with the learning using a Lectora Inspire-based interactive learning media, while those in control class using conventional method. In the end of learning, posttest was conducted on the two classes using the same question. This research was conducted in 4 meetings. 


\section{Technique and Instrument of Collecting Data}

There were some instruments used to collect data in this research:

\section{Observation}

Observation is an activity focusing on an object by using all the senses. Observation in this research was used to collect and to record important points during the learning and to see the students in the learning process. The type of observation used was systematic one for it used guidelines as observation instrument; direct observation was conducted to confirm information obtained as the attempt of solving problems occurring in the learning.

\section{Interview}

Interviews are used by researchers to determine the state of a person in response to the action taken. In this research, interview was conducted in the beginning stage of preliminary study to find out the prior condition of learning process. In addition, interview can also be used by the author as supplemental data. This is in line with the opinions Sugiyono $(2012$, p. 36) that the interview is not only used as a preliminary study to find problems that must be investigated, but it is also used when the researcher wants to know things that are deeper than the respondent. Interviews were conducted with several respondents and subject teachers concerned.

\section{Test}

Test was instrument used to find out the effectiveness of Lectora Inspire-based learning media. The test used has undertaken validity test, reliability test, difficulty level test, and item variance test.

a. Validity test

Validity test aims to measure the accuracy of instruments that will be used in a research. The validation of question items was conducted using product moment formula; the result of test analysis showed that all question items were valid, so 25 question items can be used, because $t_{\text {statistic }}$ $>t_{\text {table. }}$.

b. Reliability test

Reliability test is used to determine the consistency of measuring instruments in use. Reliability testing with the categories 0.00 to 0.20 - very low, 0.21 to 0.40 - low, 0.41 to 0.60 - enough, 0.61 to 0.80 height, 0.80 to 1.00 - very high. Considering the result of test, it could be found the test reliability score of 0.905 with very high category.

c. Variance Test

Classification of variance test consist: $\mathrm{D}=$ 0.00 to 0.20 : Ugly, $\mathrm{D}=0.20$ to 0.40 : Enough, $\mathrm{D}=0.40$ to 0.70: Good, $\mathrm{D}=0.70$ to 1.00: very good, $\mathrm{D}=$ negative, all is not well, so all items with a value of $D$ is not used. Considering the result of variance test on the question, it can be found that 8 items got fair criteria and 17 good criteria; therefore 25 question items were potentially used.

d. Difficulty Level Test

The classification of the difficulty level tests in this research consisted: $\mathrm{P} 0.00$ 0.30 is a difficult question, $\mathrm{P} 0.30-0.70$ is a medium problem, $\mathrm{P} 0.70-1.00$ is a easy problem. The result of difficulty level test showed 4 items with easy criterion and 21 with medium criterion. Considering those criteria, it can be found that all question items were likely used.

All the questions items already eligible validity test, reliability test, Variance Test, and Difficulty Level Test can be used for further research.

\section{Technique of Analyzing Data}

Data analysis in this research was conducted using statistic descriptive and t-test. The summary of Pretest and Posttest scores for experiment and Control Classes.

Table 1. Score Pretest and Posttest

\begin{tabular}{lcccc}
\hline \multirow{1}{*}{ Score } & \multicolumn{4}{c}{ Group } \\
& \multicolumn{2}{c}{ Experiment } & \multicolumn{2}{c}{ Control } \\
& Pretest & Post-test & Pretest & Post-test \\
\hline Highest score & 84 & 96 & 88 & 88 \\
Lowest score & 52 & 72 & 56 & 52 \\
Mean & 68 & 84.53 & 68.93 & 71.60 \\
Percentage & \multicolumn{2}{c}{19.56} & \multicolumn{2}{c}{3.72} \\
\hline
\end{tabular}

Source: Result of Data Processing in 2017 
The table above shows that the mean score of students' learning outcome increases by $19.56 \%$ in experiment class and only by $3.72 \%$ in control class. The result of pretestposttest on experiment and control classes was also analyzed using t-test, with analytical prerequisite conducted first including normality and homogeneity tests.

\section{Analytical Prerequisite Test}

Analytical prerequisite test was conducted to find out the feasibility of sample data used in effectiveness test. Analytical prerequisite test conducted included normality and homogeneity tests on experiment and control groups. The result of analytical prerequisite test on the pretest value is as follows:

\section{Normality Test}

Normality test was conducted to find out whether or not the sample used in this research derives from normally distributed population. Kolmogrov smirnov test was conducted with $\alpha=0.05$ and using IBM SPSS 22 program. $\mathrm{H}_{0}$ stated that the sample derives from normally distributed population; if significance value of normality test more than $\alpha$ (sig $>0.050)$ and $\mathrm{D}_{\text {statistic }}<\mathrm{D}_{\text {table }}, \mathrm{H}_{0}$ is supported. The result of normality test in this research is summarized below.

Table 2. Normality Test of Pretest on Experiment and Control Classes

\section{Tests of Normality}

\begin{tabular}{lcccccc}
\hline & \multicolumn{3}{c}{$\begin{array}{c}\text { Kolmogorov- } \\
\text { Smirnov }\end{array}$} & \multicolumn{3}{c}{ Shapiro-Wilk } \\
\cline { 2 - 7 } & Statistic & Df & Sig. & Statistic & Df & Sig. \\
\hline Experi & .121 & 30 & $.200^{*}$ & .923 & 30 & .032 \\
ment & & & & & & \\
Control & .126 & 30 & $.200^{*}$ & .932 & 30 & .156 \\
\hline
\end{tabular}

Source: Result of Data Processing in 2017

The table shows that significance value of normality test is more than $\alpha$ (sig $>0.05)$ : normality test score is $0.200>0.05$ in experiment class and $0.200>0.05$ in control class; so that it can be concluded that data of pretest cognitive score are distributed normally in both experiment and control classes.
Table 3. Normality Test of Posttest on Experiment and Control Classes

Tests of Normality

\begin{tabular}{lcccccc}
\hline & \multicolumn{3}{c}{$\begin{array}{c}\text { Kolmogorov- } \\
\text { Smirnov }^{\mathrm{a}}\end{array}$} & \multicolumn{3}{c}{ Shapiro-Wilk } \\
\cline { 2 - 7 } & Statistic & Df & Sig. & Statistic & Df & Sig. \\
\hline $\begin{array}{l}\text { Experi } \\
\text { ment }\end{array}$ & .126 & 30 & $.200^{*}$ & .913 & 30 & .017 \\
Control & .135 & 30 & .171 & .947 & 30 & .144 \\
\hline
\end{tabular}

Source: Result of Data Processing in 2017

It can be seen that significance value of normality test is more than $\alpha$ ( $\operatorname{sig}>0.05)$ : normality test score is $0.200>0.05$ in experiment class and $0.171>0.05$ in control class; so that it can be concluded that data of posttest cognitive score are distributed normally in both experiment and control classes.

\section{Homogeneity Test}

Homogeneity test was used to find out whether or not the samples compared derive from the same population. The result of homogeneity test using Levene's formula shows $\alpha=0.05$ processed using software IBM SPSS 22. The result of homogeneity test in this research is described below.

Table 4. Homogeneity test of Pretest on Experiment and Control Classes.

Test of Homogeneity of Variances

\begin{tabular}{rrrr}
\hline \multicolumn{1}{l}{ Pretest Score } & & & \\
\hline Levene Statistic & df1 & df2 & Sig. \\
\hline .098 & 1 & 58 & .755 \\
\hline
\end{tabular}

Source: Result of Data Processing in 2017

The table shows that significance score is 0.755 . The score is more than 0.05 so that it can be stated that the score of public administration learning outcome in pretest has homogeneous variance between experiment and control classes.

Table 5. Homogeneity test of Posttest on Experiment and Control Classes.

Test of Homogeneity of Variances

\begin{tabular}{lccc}
\hline Pretest Score & & & \\
\hline Levene Statistic & df1 & df2 & Sig. \\
\hline .993 & 1 & 58 & .323 \\
\hline
\end{tabular}

The Effect of Lectora Inspire-Based Interactive Learning Nur Rahmi Akbarini, Wiedy Murtini, Andre N Rahmanto 
The table shows that significance score is 0.323 . The score is more than 0.05 so that it can be stated that the score of public administration learning outcome in posttest has homogeneous variance between experiment and control classes.

\section{Effectiveness Test}

Both effectiveness test and hypothesis test in this research used t-test. Hypothesis testing with t-test is conducted to examine the effectiveness of Lectora Inspire-based interactive learning media. The criterion used in hypothesis formulation is $\alpha=0.05 . \mathrm{H}_{\mathrm{a}}$ is not supported when the significance of probability (sig) $<\alpha(0.050)$ and if the significance of probability (sig) $<\alpha(0.050), \mathrm{H}_{0}$ is supported. The result of effectiveness test and hypothesis test in this research is described as follows:

Table 6. T-test of Pretest on Experiment and Control Classes

Group Statistics

\begin{tabular}{cccccc}
\hline Class & $\mathrm{N}$ & Mean & $\begin{array}{c}\text { Std. } \\
\text { Deviation }\end{array}$ & $\begin{array}{c}\text { Std. Error } \\
\text { Mean }\end{array}$ \\
\hline \multicolumn{1}{c}{$\begin{array}{l}\text { Experi- } \\
\text { ment }\end{array}$} & 30 & 68.0000 & 10.07558 & 1.83954 \\
Score & $\begin{array}{l}\text { Class } \\
\text { Control } \\
\text { Class }\end{array}$ & 30 & 68.9333 & 9.55179 & 1.74391 \\
\hline
\end{tabular}

Source: Result of Data Processing in 2017
From the table above, it can be found that mean score of pretest is 68 in experiment class and 68.93 in control class. It indicates that the score of learning outcome is higher in control class than that in experiment class; but to prove whether there is or not a significant difference of learning outcome between experiment and control classes, t-test is conducted.

Considering t-test in the Table 7 (independent samples test) in pretest between experiment and control classes, it can be found that significance value of t-test is 0.714 . The significance value is more than 0.05 meaning that $\mathrm{H}_{0}$ is supported, with $\mathrm{t}_{\text {statistic }}$ of $-0,368<\mathrm{t}_{\text {table }}$ 2.00172. It indicates that there was no significant difference of mean score of students' learning outcome between experiment and control class during pretest; then experiment class was treated using Lectora Inspire-based interactive learning media, while control class was not.

Interactive learning media was selected so that students can participate actively in learning. Active attitude of students will foster greater interest and impact on learning outcomes for the better.

Experimental class treated differently with additional media-based interactive learning lectora inspire. Teacher expectations that learning outcomes will increase and learning can be more effective using such treatment. It turns out that the treatment has paid off well. The results of t-test post test can be explained as follows Table 8.

Table 7. Independent Samples Test of Pretest on Experiment and Control Classes

Independent Samples Test

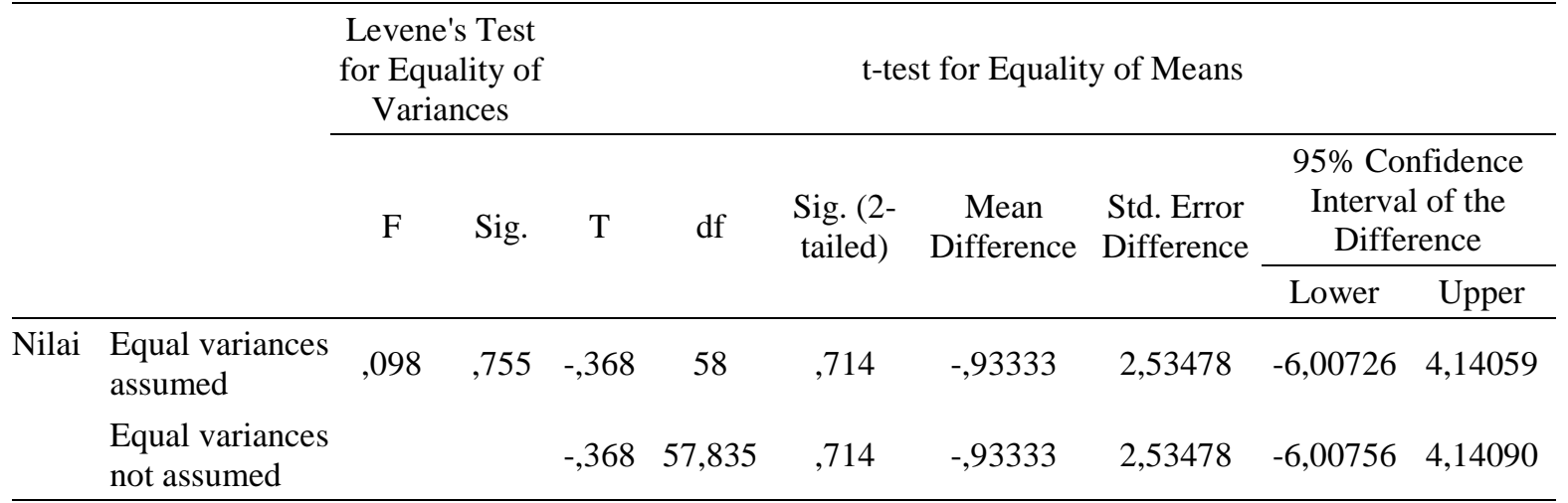

Source: Result of Data Processing in 2017 
Table 8. T-test of Posttest on Experiment and Control Classes

\begin{tabular}{cccccc}
\multicolumn{6}{c}{ Group Statistics } \\
\hline Class & $\mathrm{N}$ & Mean & $\begin{array}{c}\text { Std. } \\
\text { Deviation }\end{array}$ & $\begin{array}{c}\text { Std. Error } \\
\text { Mean }\end{array}$ \\
\hline \multirow{2}{*}{ Score } & $\begin{array}{l}\text { Experi- } \\
\text { ment }\end{array}$ & 30 & 84,5333 & 8,25346 & 1,50687 \\
& $\begin{array}{l}\text { Class } \\
\text { Control } \\
\text { Class }\end{array}$ & 30 & 71,7333 & 9,79420 & 1,78817 \\
\hline
\end{tabular}

Source: Result of Data Processing in 2017

The result of posttest scoring shows that mean score of posttest is 84.53 in experiment class and 71.73 in control class. Considering the result, it can be found that the learning outcome score of experiment class is higher than that of control class. These results indicate a significant change.

The score of experiment class is 68 before using Lectora Inspire-based interactive learning media (pretest) and 84.53 after using it (posttest). Considering the increase in the mean score of students' learning outcome in public administration subject from before (pretest) to after (posttest), it can be found that the Lectora Inspire-based interactive learning media improves the students' learning outcome effectively in public administration subject.

The result of t-test in the Table 9 (independent samples test) during posttest on experiment and control class shows that significance value of t-test is 0.000 . This significance value is less than 0.05 meaning that $\mathrm{H}_{1}$ is supported and ${ }_{\text {statistic }}$ is 5.747 $>\mathrm{t}_{\text {table }} 2.00172$. It indicates that there is a significant difference of mean score for students' learning outcome between experiment and control class.

This result suggests that experiment class has learning outcome better than the control class does, meaning that experiment class using Lectora Inspire-based interactive learning media obtains mean score of posttest higher than the control class not using it does.

The characteristics of Lectora Inspirebased interactive learning media in public administration subject are: usable and can be installed in laptop set and personal computer, thereby is more accessible. Elena (2013, p. 68) states that "The shift from machinecentered automation to user-centered services and tools is enabling users to be more creative and achieve more". When educators are creative and always provide interactive media, the students will always be interested in the learning (Nazir, 2012). It can improve the learning effectiveness indirectly.

Interactive learning media leads to two way communication between teachers and students, this interaction process will automatically increase student activity and impact on learning outcomes. The findings of this study were supported by previous research results, that the Lectora-Inspire based interactive learning media have significant effects to increase the students learning outcome (Astutik \& Rusimamto, 2016; Zuhri \& Rizaleni, 2016; Prasetyo, 2015; Faruk, 2014; Wijaya, Slamet, \& Said, 2014; Rahmawati \& Iroah, 2013).

Table 9. Independent Samples Test of Posttest on Experiment and Control Classes

\begin{tabular}{|c|c|c|c|c|c|c|c|c|c|c|}
\hline \multicolumn{11}{|c|}{ Independent Samples Test } \\
\hline & & $\begin{array}{l}\text { Leven } \\
\text { for Equ } \\
\text { Vari }\end{array}$ & $\begin{array}{l}\text { 's Test } \\
\text { ality of } \\
\text { nces }\end{array}$ & \multicolumn{7}{|c|}{ t-test for Equality of Means } \\
\hline & & \multirow[t]{2}{*}{$\mathrm{F}$} & \multirow[t]{2}{*}{ Sig. } & \multirow[t]{2}{*}{$\mathrm{T}$} & \multirow[t]{2}{*}{ df } & \multirow[t]{2}{*}{$\begin{array}{l}\text { Sig. (2- } \\
\text { tailed) }\end{array}$} & \multirow{2}{*}{$\begin{array}{l}\text { Mean } \\
\text { Differe } \\
\text { nce }\end{array}$} & \multirow[t]{2}{*}{$\begin{array}{l}\text { Std. Error } \\
\text { Difference }\end{array}$} & \multicolumn{2}{|c|}{$\begin{array}{l}\text { 95\% Confidence } \\
\text { Interval of the } \\
\text { Difference }\end{array}$} \\
\hline & & & & & & & & & Lower & Upper \\
\hline \multirow{2}{*}{ Nilai } & $\begin{array}{l}\text { Equal variances } \\
\text { assumed }\end{array}$ & ,993 & ,323 & 5,747 & 58 & ,000 & $\begin{array}{c}12,8000 \\
0\end{array}$ & 2,33842 & 8,11915 & 17,48085 \\
\hline & $\begin{array}{l}\text { Equal variances } \\
\text { not assumed }\end{array}$ & & & 5,747 & 56,380 & 000 & $\begin{array}{c}12,8000 \\
0\end{array}$ & 2,33842 & 8,11628 & 17,48372 \\
\hline
\end{tabular}

Source: Result of Data Processing in 2017 
The result of this study shows that there is an increase of student learning outcomes using Lectora-Inspire based interactive learning media rather than those who didn't using the media. Successful learning can be achieved with certain efforts that focus on the objectives set at the beginning of learning (Dirgatama, Siswandari, \& Indrawati, 2017, p. 255). This is in line with Trianto (2010, p. 24) states that the effectiveness of learning is a useful outcome in the implementation of learning activities.

\section{CONCLUSION}

The Lectora-Inspire based interactive learning media improves the students' learning outcome effectively. The mean score of learning outcome gained shows that the students respond to Lectora-Inspire based interactive learning media positively. This effectiveness builds on the improvement of students' learning outcome, as indicated with the mean score of 68 in pretest and 84.53 in posttest during operational field test. The use of Lectora Inspire-based interactive learning media improves the learning outcome of students effectively, with significance value $=$ $0.000<0.05$ during effectiveness test on experiment and control class showing a very significant difference, in which the mean score of experiment class is 84.53 , while that of control class is 71.73 .

Considering the result of research and development on Lectora Inspire-based interactive learning media, the following recommendations can be given. First, to Headmastes. The headmasters are recommended to appeal to and to encourage the teachers to develop creative and innovative learning media in order to improve the quality of school.

Second, to Teachers. Teachers are expected to be willing to learn using technologybased media to develop their ability of delivering learning material, in this case, Lectora Inspire interactive learning media. Third, to further Researchers. This research can be used as the reference for the similar studies by developing Lectora Inspire-based learning media and the wider development can be conducted to provide high-quality learning source.

\section{REFERENCES}

Astutik, M., \& Rusimamto, P. (2016). Pengembangan media pembelajaran multimedia interaktif berbantuan software Lectora Inspire untuk meningkatkan hasil belajar pada mata pelajaran teknik listrik di SMK Negeri 2 Surabaya. Jurnal Pendidikan Teknik Elektro. 05 (01), 107-114.

Budiyono. (2003). Metodologi penelitian pendidikan. Surakarta: UNS Pres.

Çelik, S. (2012). Development of usability criteria for e-learning content development software. Turkish Online Journal Of Distance Education, 13 (2), 336-345.

Dirgatama, L., Siswandari., \& Indrawati, C. D. (2017). The Effectiveness of Archieved E-Book Based Curriculum 2013 As An Effort To Improving Outcomes in Vocational School. Journal of Education and Learning. 11 (3), 251256.

Elena, R. (2013). An overview of textbooks as open educational respurces.

International Journal Of Computer Science Research and Application, 3(1), 68-73.

Faruk, A. (2014). Development of interactive learning media based Lectora Inspire in discrete method course. In International Conference on Research, Implementation, and Education of Mathematics and Science. Universitas Negeri Yogyakarta.

Leow, F., \& Neo, M. (2014). Interactive multimedia learning: Innovating classroom education in a malaysian university. TOJET : The Turkish Online Journal of Educational Technology, 13(2) Retrieved from http://www.tojet.net/articles/v13i2/1321 1.pdf

Hamalik, O. (2009). Proses belajar mengajar. Bandung: Bumi Aksara

Mas'ud, M. (2014). Tutorial 1 membuat multimedia pembelajaran dengan Lectora Inspire. Yogyakarta: Pustaka Shonif. 
Minkova, Y. (2016). Contemporary multimedia authoring tools. International Journal Of Engineering Science and Computing, 6(10), 135-162.

Naz, A. A., \& Akbar, R. A. (2008). Use of media for effective instruction its importance: some consideration. Journal of Elementary Education, 18 (1-2), 3540.

Nazir, M . I. J. (2012). Skill development in multimedia based learning environment in higher education: an operational model. International Journal of Information and Communication Technology Research, 2(11), 820-828.

Ogott, G.O., \& Odera, F.Y. (2012). Integration of media and technology in teaching and learning Kiswahili Language in secondary schools in Siaya County, Kenya. International Journal Of Information and Communication Technology Research, 2(10), 787-794.

Prasetyo, S. (2015). Pengembangan media Lectora Inspire dalam pembelajaran sains di Madrasah Ibtidiyah. Jurnal Pendidikan Islam, IV(2), 319-337.

Rahmawati, A., \& Isroah. (2013). Penggunaan media Lectora Inspire X. 6 untuk meningkatkan hasil belajar siswa SMK Ma'arif 1. Jurnal Pendidikan Akuntansi Indonesia, XI(2), 91-98.

Rifa'i, A \& Anni, C. T. (2011). Psikologi pendidikan. Semarang: UNNES Press.

Sugiyono. (2012). Metode penelitian kuantitatif, kualitatif, dan $R \& B$. Bandung: Alfabeta.
Sugiyono. (2016). Metode penelitian \& pengembangan. Bandung: Alfabeta

Trianto. (2010). Mendesain Model-Model Pembelajaran Inovatif Progresif. Jakarta: Kencana Media Pranada Group.

Weigel, M. (2009). Learning: peering backward and looking forward in the digital era. International Journal of Learning and Media, 1(1), 1-18.

Wibisono, W., Baedowi, B., \& Indrawati, C. D. S. (2017). The effectiveness of archiving simulation video in Vocational High School. Jurnal Pendidikan Vokasi, 7(2), 203-2013.

https://doi.org/10.21831/jpv.v7i2.13951

Wijaya, A. H., Slamet, L., \& Said, D.L. (2014). Pengaruh aplikasi Lectora Inspire berbasis ICT sebagai media pembelajaran interaktif pada mata diklat SOD terhadap hasil belajar siswa kelas $\mathrm{x}$ jurusan teknik komputer jaringan SMKN 1 Tanjung Baru. Jurnal Voteknika, 2(2), 7-12.

Wirawan, A. W., Indrawati, C. D. S., \& Rahmanto, A. N. (2017). Pengembangan media pembelajaran kearsipan digital untuk meningkatkan hasil belajar siswa SMK Negeri 3 Surakarta. Jurnal Pendidikan Vokasi, 7(1), 78-86. https://doi.org/10.21831/jpv.v7i1.12879

Zuhri, M. S., \& Rizaleni, E. A. (2016). Pengembangan Media Lectora Inspire dengan Pendekatan Konstekstual Pada Siswa SMA Kelas X. Phytagoras, 5 (2), 113-119. 